\title{
Review
}

\section{Pragmatism and justice}

Susan Dieleman, David Rondel, and Christopher Voparil (Eds.)

Oxford, Oxford University Press, 2017, xvii + 334pp.,

ISBN: 978-0-19-045924-6

Contemporary Political Theory (2019) 18, S236-S239. https://doi.org/10.1057/s41296018-0261-0; published online 28 October 2018

William James once described pragmatism as a corridor in a hotel. Diverse philosophical projects are taking place in the connecting rooms, but the different 'guests' must use pragmatism to communicate with each other. Pragmatism's empirical methodology and its focus on concrete practical problems supposedly makes it the perfect mediator. However, there is an old mystery at the heart of 'Hotel Pragmatism'. An important guest has gone missing or may never have been present at all. And this absence is made all the more conspicuous by the fact that this guest would seem to be vital to the melioristic aims and practical orientation of pragmatism. For the missing guest is justice, and pragmatists are curiously tight-lipped regarding its absence.

As such, the editors of this collection have assembled a team of forensic philosophers to get to the bottom of this mystery. The able investigators interrogate key figures in the pragmatist canon, search for clues in likely texts, and draw up tentative chalk-lines around the missing concept. The guiding question is: do pragmatists have anything useful to say about justice? At the risk of spoiling the denouement of this procedural drama, the answer is: yes. But though it seems as if all the contributors will agree on the general methodological outline of a pragmatist account of justice, it is in the disagreements about the details that the real value of this collection lies.

I would like to mention three major strengths of this collection, before looking at some of the disagreements which animate it. The first strength is cohesion. The collection consists of eighteen papers: six classic papers and twelve new contributions. The classic papers, authored by (in order of appearance) Richard Rorty, Nancy Fraser, Ruth Anna Putnam, Patricia Hill Collins, Hilary Putnam and Peter T. Manicas, have been expertly selected to ground discussion in each of the collection's three sections. In turn, the original contributions respond to these papers and to each other, and the whole collection is well arranged to present an ongoing series of discussions.

A second strength concerns the collection's engagement with typically marginalised voices. The figures traditionally recognised as canonical in pragmatist

(c) 2018 Springer Nature Limited. 1470-8914 Contemporary Political Theory Vol. 18, S4, S236-S239 
scholarship (Peirce, James, Dewey) occupied a privileged position within society, and have been criticised for ignoring the actual injustices faced by oppressed groups during their lifetimes. The absence of these voices is particularly ironic in a philosophy such as pragmatism, ostensibly committed to solving actual social problems through democratic inquiry. This collection takes this criticism seriously and recognises the important epistemic position that oppressed groups occupy concerning inquiry into injustice.

Thirdly, the collection represents a useful resource for future research. Many of the papers are primarily interested in mapping out potentially fruitful encounters between pragmatism and other traditions, such as: pragmatism and insurrectionism (José Medina); pragmatism and intersectionality (Patricia Hill Collins); and pragmatism and contemporary political theory (Robert B. Talisse). These connections are mostly just sketched, as each requires extensive further research. As such, this collection serves as a useful spring-board for researchers in the area.

I turn now to some of the book's key debates. One clear debate concerns how theoretical a pragmatist approach to justice should be. Gregory Pappas's contribution to the collection suggests that pragmatists should be as non-theoretical as possible. Pappas argues that general theory can blind us to important features of particular injustices, and so suggests that pragmatism put 'theoretical prejudices aside and try to designate how the problem is experienced at a pretheoretical level' (p. 95). Robert Talisse takes a different approach, arguing that the pragmatist must commit to a theory of justice. Without such a theory, the pragmatist will be unable to distinguish between social problems that can be solved by democratic inquiry and problems that represent a breakdown of democratic inquiry. Illegitimate democratic inquiry risks entrenching existing injustices, and so pragmatists require a theory of justice to indicate how the 'material and social resources of society must be apportioned' if democratic inquiry is to be legitimate (p. 285). Ruth Anna Putnam's contribution can be seen to occupy a middle ground: according to her analysis, 'the right level of generality is a function of the problem that confronts us' (p. 119). Too much focus on the particularity of a situation can lead to 'fragmentation' (p. 118), too little can lead to the kind of problems Pappas is concerned about.

A connected debate concerns pragmatism's relationship with non-ideal theory. Christopher Voparil aligns the pragmatist with the non-ideal theorist, on the reasonable grounds that both 'share a common orientation away from the ideal and towards social reality and experience as lived' (p. 66). Indeed, Voparil argues that pragmatism can be even less ideal than non-ideal theory, due to its contention that social knowledge must be combined with the practical development of 'affective ties of sympathetic understanding' (p. 67) if we are to solve the concrete problems the non-ideal theorist is concerned with. Matthew Festenstein, in comparison, whilst acknowledging connections between pragmatism and non-ideal theory, explores the role that ideals play in our practical inquiries. According to Festenstein's Deweyan account, ideals are not abstract and unrelated to concrete

(C) 2018 Springer Nature Limited. 1470-8914 Contemporary Political Theory Vol. 18, S4, S236-S239 S237 
experience, but rather represent hypotheses which are 'developed from [the] immanent possibilities of concrete social life' (p. 103) and which are constructed to make sense of the problems we confront. Ideals, on this account, are indispensable parts of democratic and socially oriented inquiry.

Another familiar debate concerns how realist the pragmatist should be. Occupying the more anti-realist end of the pragmatist spectrum, Susan Dieleman's paper challenges contemporary social epistemology's realist assumptions. Most social epistemologists think that a realist commitment to 'the way the world really is' is required in order to criticise narratives which contribute to oppression. Dieleman, however, argues that an anti-realist approach is preferable, as it allows for the fundamental revisability of concepts - such as gender - which is required for certain oppressed groups to achieve epistemic justice. Cheryl Misak's contribution takes the opposite view. Misak provides an illuminating outline of Oliver Wendel Holmes's legal philosophy, and its clear commitment to a realist pragmatist epistemology. In particular, Misak argues that the legitimacy of the law is based on its being the result of a democratic inquiry, and that democratic inquiry requires a realist commitment to 'standards and grounds enmeshed in the law ... which we aim to get right' (p. 299).

A fourth debate concerns how radical pragmatism can be. Recent scholarship has criticised pragmatism's commitment to incremental social progress as insufficient to combat the largest social problems we currently face. Medina formulates two versions of this criticism, drawing from the work of Cornel West and Leonard Harris:

if pragmatic meliorism is understood as a form of naïve optimism, it cannot accommodate the tragic aspects of life and the tragic aspects of American democracy (West); if pragmatic meliorism entails a commitment to reformism and gradual social change, then it leaves little or no room for radical social contestation and insurrection in American democracy and is ultimately incompatible with insurrectionism (Harris) (p. 198).

Medina's own response advocates developing a pragmatist and egalitarian account of human flourishing - drawing from Maria Stewart's insurrectionism - that allows it to be far more radical than a pragmatism focused on predictability and control. V. Denise James on the other hand, whilst certainly not advocating conservatism, explores why a pragmatist might be suspicious of 'the [revolutionary] conviction that the whole of society needed to be made anew, at once' (p. 164). According to James's contribution, Dewey was suspicious of revolutionary movements due not to their radicality but to their ideological dogmatism, in which 'Dewey saw the roots of fascism' (p. 165). Nonetheless, pragmatism can be sufficiently radical to challenge fundamental social institutions as long as radicalism is combined with fallibilism and experimentalism, and as long as we take Angela Davis's definition of radical as 'grasping at the root causes and proposing change' (p. 176). 
Colin Koopman's way of responding to the insurrectionist challenge involves presenting William James's 'double-barrelled' pragmatism as 'the only consistent pragmatism' (p. 193). The two sides of James's pragmatism are a scientific commitment to progress - subsequently taken up by Dewey - and an awareness of the tragedy, strife and 'contestation' when our ideals meet reality - subsequently explored by W.E.B. Du Bois. Mainstream pragmatism does not do justice to both sides, focusing solely on progressivism, which leads to an 'administrative conception of politics as an engineering task' (p. 182). Paul C. Taylor, too, develops a kind of dualistic approach. Following Dewey, Taylor separates pragmatism, primarily concerned with epistemology, from aesthetics. What aesthetics can offer which pragmatism alone cannot is the capacity to imagine different possibilities, and so resist existing social structures, stereotypes and injustices. As such, though Dewey's pragmatism may be insufficiently radical, his aesthetics can ground a more critical approach to existing society.

In presenting these papers in dialogue, I have not highlighted their individual merits, but all display impressive scholarship. In closing, I would like to mention a few papers that do not easily fall into the debates outlined above. Both Peter Manicas's and David Rondel's papers collect extensive textual evidence to present a convincing account of Dewey's position on justice and the political implications of James's individualism, respectively. Perhaps the most challenging paper of the collection, to a pragmatist reader, is Shannon Sullivan's contribution, questioning as it does the fundamental pragmatist belief that hope is pragmatically beneficial. Yet Sullivan's exploration of the limitations of hope when applied to the issue of racial justice is deeply pragmatic and empirically grounded, meaning that no pragmatist working on justice or race can afford to ignore it.

Overall, the book achieves what it sets out to do: it begins to solve the mystery of what pragmatists might be able to say about justice, and why they haven't said much about it until now. But, more importantly, the collection also represents the beginning of an interesting research project, indicating potential areas of future work, connections with other traditions, and staking out the key positions for further debate. As such, the collection represents a resource that will be repeatedly returned to as this area of research develops.

Neil W. Williams

University of Roehampton, London, UK neil.williams@ roehampton.ac.uk 